\title{
Ground beetle assemblages (Coleoptera, Carabidae) of the Krasiborska Kępa reserve
}

\author{
Oleg AleKSANDROWICZ, ${ }^{1}$ ANDZEJ ZAWAL, ${ }^{2}$ PRZEMYSŁAW ŚMIETANA ${ }^{3}$
}

Institute of Biology and Environmental Protection, Pomeranian University in Slupsk, Arciszewskiego St. 22b, 76-200 Słupsk, Poland, e-mail: oleg.aleksandrowicz@apsl.edu.pl

2 Department of Invertebrate Zoology \& Limnology, Institute for Research on Biodiversity, Faculty of Biology, Center of Molecular Biology and Biotechnology, University of Szczecin, 71-415 Szczecin, Wąska 13, Poland, e-mail: zawal@univ.szczecin.pl

3 Deparment of Ecology \& Environmental Protection, Institute for Research on Biodiversity, Faculty of Biology, University of Szczecin, 71-415 Szczecin, Wąska 13, Poland, e-mail: leptosp@gmail.com

Keywords NW Poland, Krasiborska Kępa reserve, fens, Carabidae, ground beetles, species richness, assemblage structure

Abstract The study was carried out from the beginning of June to the end of July 2005 in the Krasiborska Kępa reserve (UTM VV56; $53.848^{\circ} \mathrm{N}, 14.370^{\circ} \mathrm{E}$ ). Three research plots were established, representing various types of use of reedy areas: an unused reedy area, a reedy area mown in summer, and an area mown in winter. Beetles were collected in Barber traps with ethylene glycol as a preservative liquid. Seven traps were set up in each examined habitat. In total 1,145 specimens belonging to 35 species were caught. The relatively small area presented three different carabid assemblages, differing in species richness, abundance, dominance structure and ecological preferences. The highest species richness and abundance, as well as the largest representation of endangered stenobiontic hygrophilous bog species (Trechus rivularis, Carabus clathratus, Carabus menetriesi, Bembidion fumigatum, Blethisa multipunctata, and Oodes helopioides), were observed in the periodically flooded fen which was mowed in the winter.

\section{Zgrupowania biegaczowatych (Coleoptera, Carabidae) rezerwatu Karsiborska Kępa}

Słowa kluczowe północno-zachodnia Polska, rezerwat Karsiborska Kępa, torfowiska niskie, Carabidae, biegaczowate, bogactwo gatunkowe, struktura zgrupowania.

Streszczenie

W wyniku badań przeprowadzonych w czerwcu i lipcu 2005 roku, na trzech stanowiskach o charakterze torfowiskowym w północno-wschodniej części rezerwatu Karsiborska Kępa zebrano 1145 osobników należących do 35 gatunków. Na względnie małym terenie występują trzy różnych zgrupowania biegaczowatych. Różnice polegają na bogactwie gatunkowym, liczebności, strukturze dominacji i preferencjach ekologicznych. Największe bogactwo gatunkowe i liczebność, oraz największa reprezentacja przyrodnicza cennych stenobiontycznych higrofilnych torfowiskowych gatunków (Trechus rivularis, Carabus clathratus, Carabus menetriesi, Bembidion fumigatum, Blethisa multipunctata, Oodes helopioides) znajdowała się na stanowisku 3 - okresowo zalewanym torfowisku niskim, koszonym w okresie zimowym. 


\section{Introduction}

The current state of knowledge of the ground beetles of protected areas of Western Pomerania is presented in a monograph by Wolender (2013). However, attention was mainly devoted to carabid assemblages of forest and meadow habitats, while wetlands were overlooked.

There have been few faunistic studies of wetlands, floodplains and fens in Poland, and they mainly concern eastern Poland: Podlasie (Andrzejewska et al. 1986; Burakowski, Nowakowski 1993; Olejniczak 1998; Jędryczkowski, Kupryjanowicz 2005) and Masuria (Maciejewski 1998; Krzysztofiak 2001; Nietupski et al. 2008). For western Poland we can find only a study of the floodplain meadows of the middle course of the Warta River (Sienkiewicz 2003) and one concerning the marshy shores of Szare Lake and coastal forests neighborhood Świnoujście (Aleksandrowicz, Dąbkowski 2007; Radawiec et al. 2015).

The Krasiborska Kępa reserve was created to protect birds, particularly aquatic warblers. This area is an island, part of which is regularly flooded. The results of research on ground beetle assemblages inhabiting these habitats will contribute to knowledge of the specific conditions prevailing there.

\section{Study area}

The study sites were established in the north-eastern part of Krasiborska Kępa, not far from Świnoujście (NW Poland, UTM VV56; $53.848^{\circ} \mathrm{N}, 14.370^{\circ} \mathrm{E}$ ). The flora of this region is composed of reeds of various degrees of compactness and height, representing various stages of degeneration of meadow and pasture communities (Sagin 2005).

The investigation was conducted in June-July 2005.

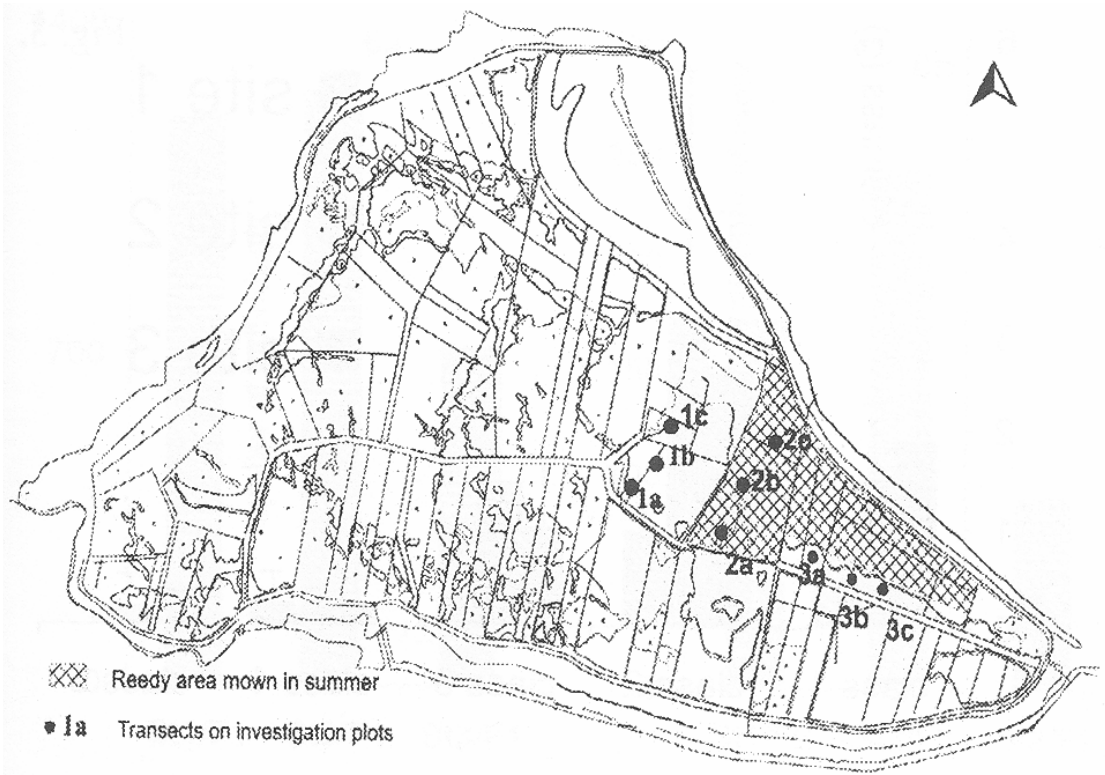

Figure 1. Location of research area 
Three research plots were established, representing various types of use of reedy areas: site 1 - an unused reedy area; site 2 - a reedy area mown in summer; site 3 - an area mown in winter (Fig. 1).

Site 1 - a diverse habitat, secondarily covered with sedges and reeds; meadow-like in some places, with a fairly dry substratum and a mixture of grasses, perennials and small patches of sedge and low reeds; in other parts it has the character of a sedge zone on a very wet substratum, sometimes wholly flooded with water, with small patches of sparse and in some places more compact reed aggregations.

Site 2 - reeds are mowed in the summer; rushes predominate in some areas, and reeds and sedges in others. The habitat was varied, composed of mosaic fragments of meadow overgrown with grasses and perennials, with patches of sedge and reeds; the reeds were mostly sparse and relatively low.

Site 3 - the habitat was relatively homogeneous and covered with compact reed growth. Small patches of sedge occurred in some places. Most of the substratum was flooded, with very wet soil visible only on slight rises of the terrain.

\section{Research methods}

The study was carried in the case of another researches (Dąbkowski, Zawal 2006) (out at three sites from 5 June to 28 July 2005. Beetles were collected in Barber traps $(9 \mathrm{~cm}$ in diameter, 0.51 capacity) with ethylene glycol as a preservative liquid. The traps were set up in rows, with 7 traps in each examined habitat. The interval between traps was about $10 \mathrm{~m}$. The traps were replaced every month. Trapping continued for 87 days.

Dominance structure was described according to the scale by Renkonen (1938): dominants - over 5\%; subdominants -4.99 - 3\%; recedents $-2.99-1 \%$; and subrecedents - less than $1 \%$. Species were characterized ecologically (preferred habitat and hygropreference) using data found in works by Lindroth (1945) and Koch (1989).

Statistical analysis was performed using BioDiversity Professional Beta 1 software.

\section{Results}

In the material collected 1,145 individuals belonging to 35 species were identified (Tab. 1).

Table 1. Species composition and abundance of specimen of carabid's assembly from different habitat of Krasiborska Kępa

\begin{tabular}{|l|c|c|c|c|}
\hline \multicolumn{1}{|c|}{ Species } & $\begin{array}{c}\text { Habitat 1. } \\
\text { Secondary } \\
\text { sedge-reed } \\
\text { rushes }\end{array}$ & $\begin{array}{c}\text { Habitat 2. } \\
\text { The rushes with } \\
\text { a considerable } \\
\text { part of reeds }\end{array}$ & $\begin{array}{c}\text { Habitat 3. } \\
\text { Flooded terrain, } \\
\text { covered with compact } \\
\text { reed growth }\end{array}$ & Total \\
\hline 1 & 2 & 3 & 4 & 5 \\
\hline Acupalpus parvulus (Sturm,1825) & & & 1 & 1 \\
\hline Agonum emarginatum (Gyllenhal,1827) & 1 & & 8 & 9 \\
\hline Agonum fuliginosum (Panzer,1809) & 2 & 7 & 3 & 12 \\
\hline Agonum hypocrita (Apfelbeck,1904) & & & 3 & 3 \\
\hline
\end{tabular}




\begin{tabular}{|c|c|c|c|c|}
\hline 1 & 2 & 3 & 4 & 5 \\
\hline Agonum lugens (Duftschmid,1812) & & 10 & 12 & 22 \\
\hline Agonum thoreyi (Dejean,1828) & & 2 & 8 & 10 \\
\hline Amara plebeja (Gyllenhal,1810) & & 1 & & 1 \\
\hline Badister bullatus (Schrank,1798) & & 1 & & 1 \\
\hline Badister peltatus (Panzer,1797) & & & 2 & 2 \\
\hline Badister unipustulatus Bonelli,1813 & & & 1 & 1 \\
\hline Bembidion assimile Gyllenhal,1810 & 1 & & 2 & 3 \\
\hline Bembidion fumigatum (Duftschmid,1812) & & & 1 & 1 \\
\hline Bembidion gilvipes (Sturm,1825) & 1 & & & 1 \\
\hline Bembidion schueppelii Dejean, 1831 & 14 & 1 & & 15 \\
\hline Blethisa multipunctata (Linnaeus,1758) & & 43 & 69 & 112 \\
\hline Carabus clathratus Linnaeus, 1761 & & & 1 & 1 \\
\hline Carabus granulatus Linnaeus, 1758 & 37 & 53 & 40 & 130 \\
\hline Carabus menetriesi Hummel,1827 & & 9 & 29 & 38 \\
\hline Chlaenius nitidulus (Schrank,1781) & & 1 & & 1 \\
\hline Chlaenius tristis (Schaller,1783) & & 10 & 32 & 42 \\
\hline Clivina fossor (Linnaeus,1758) & 2 & & & 2 \\
\hline Dyschirius globosus Herbst,1784 & 33 & & & 33 \\
\hline Harpalus rufipes (Degeer,1774) & 2 & & & 2 \\
\hline Loricera pilicornis (Fabricius,1775) & & 4 & 3 & 7 \\
\hline Oodes helopioides (Fabricius,1792) & 15 & 47 & 110 & 172 \\
\hline Oxypselaphus obscurus (Herbst,1784) & 5 & 17 & 20 & 42 \\
\hline Poecilus cupreus (Linnaeus,1758) & & 2 & & 2 \\
\hline Pterostichus diligens (Sturm,1824) & 8 & 22 & 16 & 46 \\
\hline Pterostichus gracilis (Dejean,1828) & & 4 & 6 & 10 \\
\hline Pterostichus minor (Gyllenhal,1827) & 4 & 6 & 11 & 21 \\
\hline Pterostichus nigrita (Paykull,1790) & 3 & 20 & 283 & 306 \\
\hline Pterostichus rhaeticus Heer, 1838 & & & 34 & 34 \\
\hline Pterostichus vernalis (Panzer,1796) & 17 & 28 & 15 & 60 \\
\hline Stenolophus mixtus (Herbst,1784) & & 1 & & 1 \\
\hline Trechus rivularis (Gyllenhal,1810) & & & 1 & 1 \\
\hline Number of specimens & 145 & 289 & 711 & 1145 \\
\hline Number of species & 15 & 21 & 25 & \\
\hline
\end{tabular}

The presence of single specimens of two species from the Polish Red Data Book of Animals was established: Trechus rivularis (CR - critically endangered) and Carabus clathratus (EN endangered) on the flooded fen mowed in winter (site 3).

Carabus menetriesi and Bembidion fumigatum, recorded at sites 2 and 3, are endangered (EN) species according to the Polish Red List (Pawłowski et al. 2002). Blethisa multipunctata and Oodes helopioides, considered vulnerable species (VU), are fairly abundant. Blethisa multipunctata was recorded at sites 2 and 3, and Oodes helopioides throughout the study area. 
The most specimens (711) and species (25) were recorded at site 3, and the fewest (145 specimens and 15 species) at site 1 .

The number of dominants and subdominants is similar: from 9 to 12 species (Tab. 2). Only two dominants were common to all habitats: Carabus granulatus and Oodes helopiodes. Pterostichus vernalis and Pterostichus diligens dominate in habitats 1 and 2, while Pterostichus nigrita and Blethisa multipunctata are dominant in habitats 2 and 3.

Table 2. Structure domination of carabid's assembly from different habitat of Krasiborska Kępa

\begin{tabular}{|c|c|c|}
\hline Habitat 1 & Habitat 2 & Habitat 3 \\
\hline \multicolumn{3}{|c|}{ Dominant } \\
\hline Carabus granulatus & Carabus granulatus & Carabus granulatus \\
\hline \multicolumn{3}{|l|}{ Dyschirius globosus } \\
\hline Pterostichus vernalis & Pterostichus vernalis & \\
\hline Oodes helopioides & Oodes helopioides & Oodes helopioides \\
\hline \multicolumn{3}{|l|}{ Bembidion schueppelii } \\
\hline \multirow[t]{4}{*}{ Pterostichus diligens } & Pterostichus diligens & \\
\hline & Blethisa multipunctata & Blethisa multipunctata \\
\hline & Pterostichus nigrita & Pterostichus nigrita \\
\hline & Oxypselaphus obscurus & \\
\hline \multicolumn{3}{|c|}{ Subdominant } \\
\hline \multicolumn{3}{|l|}{ Oxypselaphus obscurus } \\
\hline \multicolumn{3}{|l|}{ Pterostichus nigrita } \\
\hline Pterostichus minor & Pterostichus minor & \\
\hline \multirow[t]{7}{*}{ Agonum fuliginosum } & Agonum fuliginosum & \\
\hline & Chlaenius tristis & Chlaenius tristis \\
\hline & Carabus menetriesi & Carabus menetriesi \\
\hline & Agonum lugens & \\
\hline & & Pterostichus diligens \\
\hline & & Pterostichus vernalis \\
\hline & & Pterostichus rhaeticus \\
\hline
\end{tabular}

There were no subdominants common to all habitats. Pterostichus minor and Agonum fuliginosum are subdominants in habitats 1 and 2, and Chlaenius tristis and Carabus menetriesi in habitats 2 and 3.

These distances are confirmed by cluster analysis (Fig. 2, Tab. 3). The similarity between assemblages 2 and 3 is slightly under $50 \%$, and together their similarity to the habitat 1 assemblage is only $21.3 \%$, which indicates that the habitats are highly distinct. 


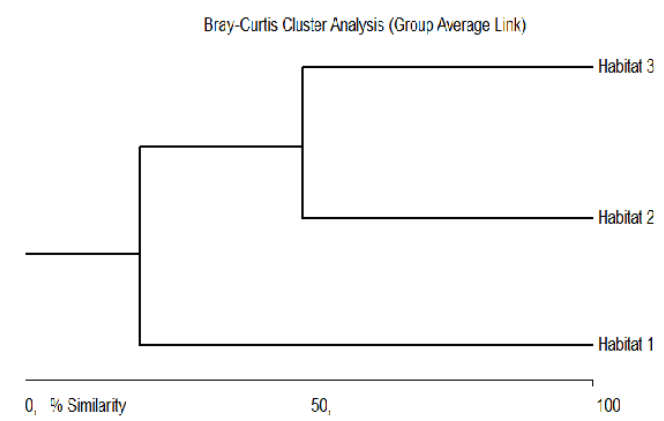

Figure 2. Denrogram of similarity (Bray-Curtis index) of carabid's assembly from different habitat of Krasiborska Kępa

Table 3. Similarity matrix of Bray-Curtis indexes for carabid's assembly of different habitat of Krasiborska Kępa

\begin{tabular}{|l|c|c|c|}
\hline & Habitat 1 & Habitat 2 & Habitat 3 \\
\hline Habitat 1 & $*$ & 42.4 & 21.3 \\
\hline Habitat 2 & $*$ & $*$ & 49.0 \\
\hline Habitat 3 & $*$ & $*$ & $*$ \\
\hline
\end{tabular}

The analysis of ecological preferences indicates dominance of eurytopic (11 species, $43.92 \%$ of individuals) and stenobiontic (10 species, $26.03 \%$ of individuals) hygrophilous peatland species (Tab. 4). Eurytopic hydrophilous forest species (2 species, 15.2\%), stenobiontic hygrophilous boundary species (4 species, 11.27\% of individuals), and mesophilous forest and field species were represented by single specimens.

Table 4. Ecological structure of carabid's assemblies of Krasiborska Kępa

\begin{tabular}{|l|c|c|}
\hline \multicolumn{1}{|c|}{ Ecological group } & $\begin{array}{c}\text { Number } \\
\text { of specimen, \% }\end{array}$ & $\begin{array}{c}\text { Number } \\
\text { of species }\end{array}$ \\
\hline Eurytopic hygrophilous campicol & 0.09 & 1 \\
\hline Eurytopic hygrophilous paludicol & 43.92 & 11 \\
\hline Eurytopic hygrophilous silvicol & 15.02 & 2 \\
\hline Eurytopic mesohygrophilous campicol & 2.97 & 2 \\
\hline Eurytopic mesophilous campicol & 0.52 & 3 \\
\hline Stenotopic hygrophilous paludicol & 26.03 & 10 \\
\hline Stenotopic hygrophilous ripicol & 11.27 & 4 \\
\hline Stenotopic halobiontic ripicol & 0.09 & 1 \\
\hline Eurytopic mesophilous silvicol & 0.09 & 1 \\
\hline Total & 1145 & 35 \\
\hline
\end{tabular}


Eurytopic mesohygrophilous field species were present only at site 1 and were mainly represented by Dyschirius globosus.

Only one specimen of a typically littoral halophilous species was captured: Bembidion fumigatum at site 3 .

A specific ecological structure was observed for each of the assemblages (Fig. 3). The only numerous common element was eurytopic hygrophilous forest species (almost exclusively Carabus granulatus), with a share ranging from $8.44 \%$ at site 3 to $28.96 \%$ at site 1 .

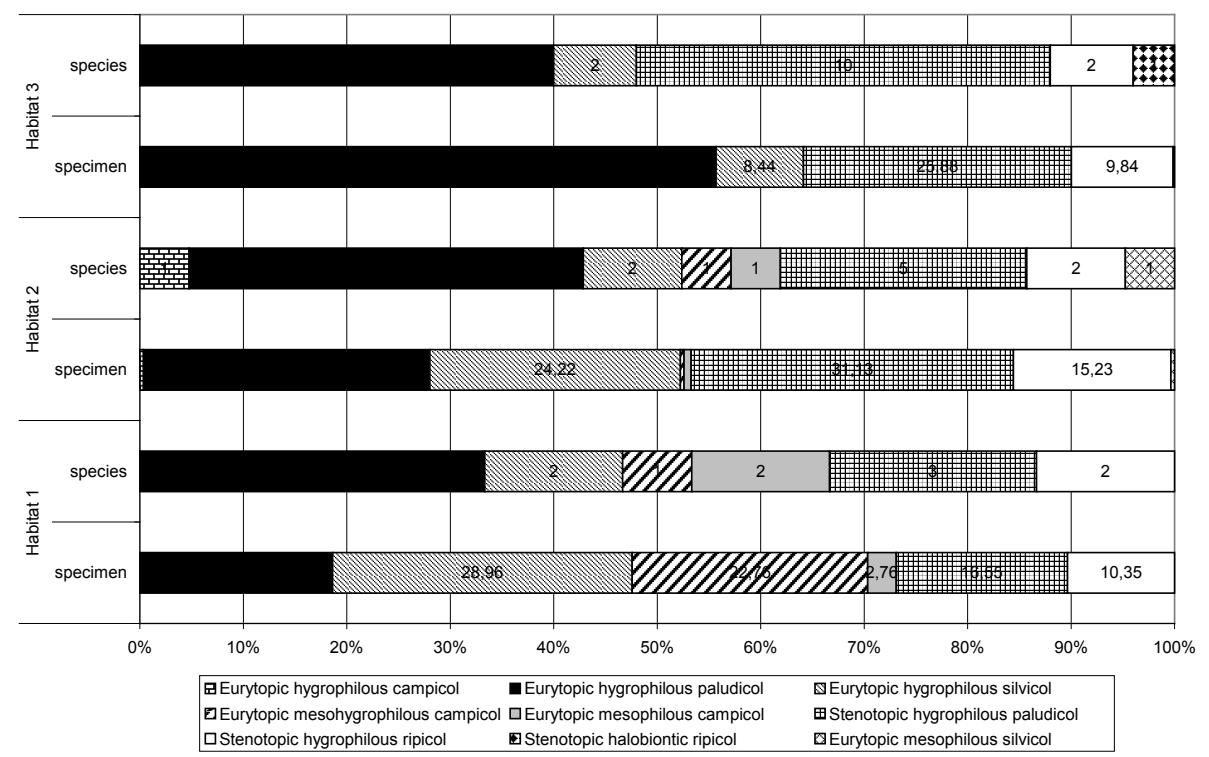

Figure 3. Ecological structure of carabid's assembly from different habitat of Krasiborska Kępa Island.

The assemblage at site 1 was the poorest in terms of species richness and the number of specimens caught. The lowest percentage of hygrophilous peatland species was noted here, but the highest percentage of eurytopic meso-hygrophilous field species (22.76\%).

The assemblage at site 3 had the highest species richness and the most specimens caught. Eurybiontic (10 species, $55.70 \%$ of individuals) and stenobiontic (10 species, $25.8 \%$ of individuals) hygrophilous peatland species were dominant here. No mesohygrophilous or mesophilous species were found here.

The assemblage at site 2 is similar to the one at site 3 , but with a lower proportion of eurybiontic peatland hygrophiles and a larger share of stenobiontic peatland hygrophiles. Here stenobiontic hygrophilous boundary species are most abundant (15.23\%), with single specimens of mesohygrophiles and mesophiles (Fig. 3).

Thus on a relatively small area three different assemblages of ground beetles are represented. The greatest species richness and abundance and the greatest number of valuable stenobiontic hygrophilous peatland species were found at site 3 - a periodically flooded fen mown in the winter. 


\section{Discussion}

In ecological terms the assemblages studied were composed mainly of hygrophilous eurytopic and stenotopic species characteristic of peatlands and wetlands.

There have been virtually no studies on the carabid fauna of lowland peatlands in Western Europe, due to the large-scale drainage of peatlands and their further use for crops or pastures (Thiele 1977).

Species richness in ground beetle assemblages of fens of Poland and Belarus usually ranges between 10 and 50 species (Aleksandrowicz 2014). The presence of 35 species in the material collected indicates high species richness in the assemblages. The dominance of hygrophilous species, in terms of both number of species and abundance, is typical of peatlands.

The dominants and subdominants in the assemblages of Krasiborska Kępa, i.e. Carabus granulatus, Oodes helopioides, Pterostichus vernalis, Dyschirius globosus and Pterostichus nigrita, were also dominant in the peatlands of Biebrza National Park (Olejniczak 1998; Jędryczkowski, Kupryjanowicz 2005), Belarusian Polesie and Białowieża Forest (Aleksandrowicz 2014).

Carabus menetriesi is a subdominant only in the peatlands of Belarusian Polesie and Krasiborska Kępa.

The assemblage in the periodically flooded fen which is mowed in winter has the greatest natural value. It includes all species in Poland in categories CR (Trechus rivularis), EN (Carabus clathratus, Carabus menetriesi and Bembidion fumigatum) and VU (Blethisa multipunctata and Oodes helopioides).

A unique feature of the assemblages of Krasiborska Kępa is the dominance of Blethisa multipunctata and Oodes helopioides, species which are vulnerable in Poland (VU) (Pawłowski et al. 2002).

\section{Conclusions}

As a result of the study conducted in June and July of 2005 on three peatland sites in the northeastern part of the Krasiborska Kępa reserve, 1,145 individuals belonging to 35 species were collected.

On a relatively small area three different assemblages of ground beetles were observed. The differences noted were in species richness, abundance, dominance structure and ecological preferences.

The greatest species richness and abundance, as well as the highest number of valuable stenobiontic hygrophilous peatland species (Trechus rivularis, Carabus clathratus, Carabus menetriesi, Bembidion fumigatum, Blethisa multipunctata and Oodes helopioides), were observed at site 3 - a periodically flooded fen mown in the winter.

\section{References}

Aleksandrowicz O. 2014. Ground beetles (Coleoptera, Carabidae) west of the forest zone of the Russian Plain. Fauna, zoogeography, ecology, faunogenesis. Lambert Academic Publishing, Saarbrücken.

Aleksandrowicz O., Dąbrowski P. 2007. Wstępne badania nad fauną chrząszczy epigeicznych (Coleoptera) okolic rezerwatu przyrody “Jezioro Szare”. Parki Narodowe i Rezerwaty Przyrody, 26 (4): 115-120.

Andrzejewska L., Chmielewski K., Kaczmarek M., Kajak A., Wasilewska L. 1986. The effect of peat meadow management on biocoenosis. Polish Ecological Studies, 11 (1): 53-78. 
Burakowski B., Nowakowski E. 1993. Beetles (Coleoptera) of meadows on peat soils in Biebrza Valley. Zeszyty Problemowe Postępów Nauk Rolniczych. 3: 153-159.

Dąbkowski P., Zawal A. 2006. Potential food resources of the Aquatic Warbler (Acrocephalus paludicola) viewed against the background of protection nesting sites in the area of Krasiborska Kepa (Western Pomerania). Polish Journal of Environmental Studies, 15 (5d): 742-747.

Jędryczkowski W.B., Kupryjanowicz J. 2005. Biegaczowate, Carabidae (Chrząszcze, Coleoptera) czterech środowisk Biebrzańskiego Parku Narodowego. In: Przyroda Biebrzańskiego Parku Narodowego. A. Osowiec-Twierdza (ed.). Biebrzański Park Narodowy, pp. 325-329.

Koch K. 1989. Die Käfer Mitteleuropas. Ökologie. Goecke \& Evers Verlag, Krefeld.

Krzysztofiak L. 2001. Biegaczowate (Carabidae) Wigierskiego Parku Narodowego. Rocznik Augustowsko-Suwalski, 1: 55-65.

Lindroth C.H. 1945. Die fennoskandichen Carabidae. Eine tiergeographisce Studie. 1. Spezieller Teil. Göteborgs Kungl.: Vetenskaps-och Vitterhets-Samhalles, 4: 1-709.

Maciejewski K.H. 1998. Ocena bioróżnorodności środowisk leśnych Puszczy Boreckiej na przykładzie chrzaszczy epigeicznych. PhD Thesis, University of Mikołaj Kopernik in Toruń [manuscript].

Nietupski M., Ciepielewska D., Kosewska A. 2008. Assemblages of epigeic Carabidae (Col.) in a peatbog Nature Reserve situated in an urban area. Polish Journal of Natural Sciences, 23(3): 611-623.

Olejniczak I. 1998. The carabid communities of natural and drained peatlands in the Biebrza valley, NE Poland. Polish Journal of Ecology, 46 (3): 243-260.

Radawiec B., Baran Ł., Zawal A. 2015. A contribution to knowledge of the ground beetles (Insecta, Coleoptera: Carabidae) of Wolin Island. Acta Biologica, 22: 197-212. DOI 10.18276/ab.2015.22-14.

Renkonen O. 1938. Statistisch-ökologische Untersuchungen über die terrestrische Käferwelt der finnischen Bruchmoore. Ann. Zool. Soc. Zool.-Bot. Fennicae Vanamo, 6 (1): 1-231.

Sągin P. 2005. Raport z prowadzonego w 2005 roku monitoringu struktury zbiorowisk roślinnych w rejonie stosowania czynnej ochrony siedlisk wodniczki na Karsiborskiej Kepie, unpubl. Technical report, OTOP, Szczecin: 4-15.

Sienkiewicz P. 2003. Ground beetles (Coleoptera: Carabidae) of the seasonally flooded meadows in the valley of the middle course of the Warta qualitative analysis. Baltic Journal of Coleopterology, 3 (2): 129-136.

Thiele H.U. 1977. Carabid beetles in their environments. A study on habitat selection by adaptations in physiology and behaviour. Berlin, Heidelberg, New York.

Wolender M. 2013. Biegaczowate (Coleoptera, Carabidae) obszarów chronionych Zachodniego Pomorza. Studium faunistyczno-ekologiczne. Zachodniopomorski Uniwersytet Technologiczny w Szczecinie. Szczecin.

Cite as: Aleksandrowicz O., Zawal A., Śmietana, P. 2016. Ground beetle assemblages (Coleoptera Carabidae) of the Krasiborska Kępa reserve. Acta Biologica, 23: 5-13. DOI: 10.18276/ab.2016.23-01. 